\title{
From the letter to the spirit of the law. Exploratory research on language in behaviourally-informed EU law
}

De la lettre à l'esprit de la loi. Explorations sur la langue dans le droit européen influencé par les sciences comportementales

\section{Anne Brunon-Ernst}

\section{OpenEdition}

\section{Journals}

\section{Electronic version}

URL: http://journals.openedition.org/asp/4903

DOI: $10.4000 /$ asp.4903

ISSN: 2108-6354

\section{Publisher}

Groupe d'étude et de recherche en anglais de spécialité

\section{Printed version}

Date of publication: 1 November 2016

Number of pages: $87-105$

ISSN: 1246-8185

Electronic reference

Anne Brunon-Ernst, « From the letter to the spirit of the law. Exploratory research on language in behaviourally-informed EU law », ASp [Online], 70 | 2016, Online since 01 November 2017, connection on 01 November 2020. URL : http://journals.openedition.org/asp/4903; DOI : https://doi.org/10.4000/ asp.4903

This text was automatically generated on 1 November 2020

Tous droits réservés 


\title{
From the letter to the spirit of the law. Exploratory research on language in behaviourally-informed EU law
}

\author{
De la lettre à l'esprit de la loi. Explorations sur la langue dans le droit européen \\ influencé par les sciences comportementales
}

Anne Brunon-Ernst

It appears that insurance is bought as protection against worry, not only against risk, and that

worry can be manipulated by labelling of outcomes and by the framing of contingencies.

(Tversky \& Kahneman 1981: 457)

\section{Introduction}

In the field of social control research, the first decades of the 21st century have been marked by the analyses of increasingly efficient regulation policies. These policies are usually referred to under the umbrella concept of nudges. The term was coined by Cass Sunstein and Richard Thaler (Sunstein \& Thaler 2008). To overcome the catch-all use of the concept, precise distinctions are explored in Section 1. However, a definition will help highlight the general argument. A nudge is defined as an "initiative that maintains freedom of choice while also steering people's decisions in the right direction" (Sunstein 2014: 17). Why do people's decisions need to be steered in the right direction? Because they are prone to taking the wrong decisions. Human behaviour is a far cry from the rational decision-making of Econs, which is the name given to the rational idealised beings used in classical economic theory (Sunstein \& Thaler op. cit.: 17-102). Behavioural economics uses psychological studies to explain economic decision-making and to highlight the predictable cognitive biases affecting human action. This 
predictability makes behavioural science very attractive for companies. For example, salespersons use automatic, fixed action patterns (which are also called "trigger features") to increase sales (Cialdini 2007: 5-11).

Consumers' decisions are thus affected by cognitive biases preventing them from making the rational choices needed to increase their overall welfare. As crafty sellers design contracts to tap into these systematic misconceptions, in the name of social justice, governments intervene in consumer contracts to impose mandatory guidelines in order to correct any unfairness, imbalance or bias which tilts the benefits of the transaction to the sellers' advantage. The study of the implementation of some of these government initiatives in the airline industry constitutes the main topic of the present paper.

3 The European Union has set up the Foresight and Behavioural Insights Unit to identify, propose and coordinate initiatives in the EU which rely on findings in behavioural sciences. Interestingly enough, some of those initiatives either restrict the way in which information is given and/or an agreement is sought, ${ }^{1}$ or request a neutral formulation. ${ }^{2} \mathrm{EU}$ legislation can impose strict linguistic guidelines on sellers. This paper looks into how some companies comply with these linguistic obligations and/or misrepresent them, ${ }^{3}$ thanks to the use of a technique called framing.

Section 1 starts with the theoretical and legal framework of behaviourally-informed policies. Then Section 2 explores the ways in which seven airline companies (AerLingus, BA, Easyjet, Flybe, Jet2, Monarch and Ryanair) comply with EU laws, in relation to the provision of insurance services at the time of the purchase of a travel ticket. The different linguistic strategies used by the companies are examined. They show that the framing ${ }^{4}$ of the information (Tversky \& Kahneman op.cit.: 453) is key to ensuring legal compliance. However, paradoxically, businesses' strict legal compliance can display a high level of misrepresentation, which seeks to overturn the effects of any EU behaviourally-informed initiative. Further investigations show that a narrative strategy is key to understanding the theoretical efficiency of the seller's framing of the government mandate.

\section{Theoretical and legal context}

\subsection{The conceptual maze: nudges and other related concepts}

5 Nudges are only part of the wide array of regulatory instruments available to modify behaviour. As outlined in the introduction, nudges are very specific types of initiatives. Three conditions need to be met for an element to be considered as a nudge. First, nudges - like a wide range of policy tools - are about modifying people's behaviour by redefining the environment in which they make choices thanks to the understanding of their psychological motives. What distinguishes them from other similar initiatives are the next two conditions: reversibility and benevolence. Indeed, the second condition states that nudged individuals are not forced to modify their behaviour. Even if the preferred option is more likely, they still have the choice to select another option, that is to reverse the nudge (Sunstein 2014: 17). A.-L. Sibony and A. Alemanno explain that a nudge is a distinctive, alternative way, characterised as being minimally burdensome, low-cost and choice-preserving, to help promote regulatory goals (2015: 5). Third, environments are designed to maximise choice according to certain goals (political, 
health-related, economic, etc.), which are seen as good for the person nudged (nudgee) by the person nudging him/her (nudger). This third condition excludes almost all business-related initiatives, since businesses aim to improve profits at the expense of consumers, contrary to government-initiated policies.

6 As the present study looks into mandatory guidelines seeking to overturn businesses' unfair practices, nudge - and its converse counter-nudge - is too limited a concept to describe the relationship between businesses and EU legislation. Indeed, nudgers (and soft-paternalists or libertarian paternalists) are interested in initiatives which are easy to overcome (that is low-cost initiatives which are easy for nudgees not to follow), and this focus generally seems compatible with non-legal means of regulation rather than legislation, which is the preferred option of hard-paternalists. There are many more terms available on the marketplace of ideas, such as paternalism (Conly 2013: 48), ${ }^{5}$ choice architecture (Sunstein op. cit.: 14), ${ }^{6}$ contract design (Bar-Gill 2012; Brunon-Ernst 2015), 7 or behavioural insights (BIs).

7 The European Commission advocates the use of the concept of BIs to describe a certain number of initiatives, which are said to be either behaviourally-informed or behaviourally-aligned, depending on the level of behavioural awareness of the policymakers. BIs use the findings of economics, psychology and neuroscience to understand how people behave and make decisions (Sousa Lourenco et al. 2016: 12).

\subsection{Behavioural insights and EU law}

The example of the picture of flies in urinals to improve cleanliness in public lavatories for men, or markings on roads to enhance road safety are well-known. However, the present paper does not explore that type of nudging. It focuses rather on the legal applications of BIs. Notwithstanding the use of nudges as low-cost initiatives (that is non-legally binding), behaviourally-informed policies can also be found in law. They can be modestly added to an array of regulatory tools, with the aim of enhancing their effectiveness (such as the imposition of mandatory linguistic guidelines in contracts), ${ }^{8}$ or represent policy tools in their own right (such as making organ donation the default option in a country). ${ }^{9}$

Public intervention in the field of consumer protection predates the development of behavioural policy applications. In Great Britain, the Unfair Contract Terms Act was passed in 1977. It remains an early example of a law where the choice-making process or bias was taken into account for the implementation of a solution against unfair contractual terms. This is now retrospectively called a behaviourally-aligned initiative (Sousa Lourenco et al. op. cit.: 16). A more systematic and scientific approach to policy making is now spreading thanks to Behavioural Units around the world, ${ }^{10}$ which aim to increase welfare by devising behaviourally-informed policies.

The European Union has produced directives and legal provisions preventing sellers from tapping into consumer cognitive biases mainly in the fields of data protection (Carolan \& Spina, 2015: 161-78; Zuiderveen Borgesius 2015: 179-208), consumer protection (Sibony \& Helleringer 2015: $213 \mathrm{n} .15$ ), ${ }^{11}$ health (Alemanno 2015: 235-54) and finance (Van Cleynenbreugel, 2015: 255-276), but also energy (Van Bavel et al. 2013), ${ }^{12}$ taxation (idem), ${ }^{13}$ transport $^{14}$ and employment (id.). As the present paper centres on consumer law, the rest of the discussion will focus on behavioural initiatives devised to 
counter systematic consumer misconceptions, which can affect perception of the scope of the agreement, ${ }^{15}$ its product features and its use patterns (Bar-Gill 2012: 3).

11 Consumer psychological flaws are well-mapped in the literature. Three categories stand out: first, the human limitations to processing information (Avgoulea op. cit.: 440f; Ayres \& Schwartz op. cit:: 545f) ${ }^{16}$ second, the consistency and commitment rule, of which the sunk-cost effects (Arkes \& Blumer 1985: 124-40; Cialdini op. cit.: 57-113), ${ }^{17}$ cognitive dissonance (Aronson 1995: 178-9; Cialdini, op. cit.: 57-113), ${ }^{18}$ confirmation bias (Plous 1993: 233) ${ }^{19}$ and even the herding effect (Avgoulea, 2009: 440f; Ayres \& Schwartz 2014: $545 f),{ }^{20}$ can be construed as an instance; and third, consumer over confidence (idem) ${ }^{21}$ (which is also exemplified in the low-ball technique [Becher 2007: 133-5]), ${ }^{22}$ the low-probability risk, ${ }^{23}$ the availability cascade (Becher op. cit.: 144-147) ${ }^{24}$ and the selfserving biases (Becher op. cit.: 147-50). ${ }^{25}$ All these cognitive biases are used by businesses firstly to devise selling practices to overload the consumer with nonrelevant information so as to spark off automatic stereotyped responses, secondly to extract a small concession on the part of prospective buyers to trigger the consistency and commitment effect, ${ }^{26}$ or thirdly to refer to peers to ensure consumers underestimate risks and follow the herd of uninformed consumers before them. Behavioural economic studies show that the standard rational choice paradigm is both theoretically unable to account for these predictable consumer biases, and practically unsuited to devise public policies accordingly (Noll \& Krier 1990: 747-779).

The EU Foresights and Behavioural Insights Unit has thus identified a certain number of BI initiatives that contribute to fighting the psychological flaws listed above. ${ }^{27} \mathrm{~A}$ first series of initiatives tackles the limited human ability to process an uninterrupted flow of information. It endorses simplification, thus reducing the amount of information available (quantity), and salience (such as smart disclosures), thus highlighting relevant information (quality) (Alemanno \& Sibony 2015: 10-9).

A second series of initiatives concerns the status quo bias, that is the preference for an existing state of affairs. The use of social norms invokes accepted or prevalent behaviour among peers, and default assigns a preferred option (approved by mandatory guidelines). Some initiatives also make use of a bias well documented by behavioural economists: loss aversion, which refers to the fact that, if given the choice, people will prefer not to lose an item rather than to gain one (Kahneman 2011). ${ }^{28}$

However, in the context of the present study on language and behaviourally-informed EU law, the focus of policies on the way in which the message is designed is paramount. It is what the EU Unit calls framing and affect (Sousa Lourenco et al. op. cit.; Avgoulea op. cit.: 440f; Ayres \& Schwartz op. cit.: 545f; Becher op. cit.: 147-50). ${ }^{29}$

\subsection{Aim of the study}

15 A certain number of assumptions need to be made at the end of Section 1 . The first is that airline companies comply with the mandatory provisions imposed by EU law. The second is that, notwithstanding this compliance, companies endeavour to avoid the negative impact of compliance on sales by finding legally compliant ways of framing the agreement in order to make purchase of insurance likely.

This last assumption is based on well-documented company strategies. Since 1972, the Federal Trade Commission has promulgated federal trade rules to address unfair and deceptive trade practices in sales conducted in locations other than the place of 
business of the seller. ${ }^{30}$ These rules allow consumers a few days to cancel their purchase and receive a full refund. In the wake of these rules, door-to-door sales plummeted. Some sellers responded to the drop by turning to other sales strategies, such as asking the customer to fill in the agreement form (this was previously done by the salesperson him or herself). Psychology shows that if individuals commit in writing, they are more likely to stand by their commitment, in the name of consistency (Cialdini op. cit.: 57113). Indeed, in our example, the number of cancellations dropped after the change of procedure (idem: 79).

This is a telling example. It underlines the fact that behaviourally-informed government initiatives are a three-level process. The first level relates to the sellers. They use their knowledge of behavioural economics (or their intuition thereof) to maximise sales by exploiting consumer failings. The second level involves the government. Its increased awareness of cognitive biases and the way in which they are abused by businesses (as verified in the studies carried out by Behavioural Units) triggers its intervention to protect consumers. The threshold for government interference is aptly described in Directive 2005/29 as a commercial practice causing the consumer "to take a transactional decision that he would not have taken otherwise" (Dir. 2005/29, Ch. 2, s. 1, Art. 6, §1 and §2; s. 1, Art. 7, §1 and §2; s. 2, Art. 8). To use concepts loosely, it could also be said that the business nudge is then counternudged by the government initiative. Government policies are also implemented with an eye to behavioural and economic insights. In the same directive, the rationale for policies is to protect consumers from "psychological pressure" (CDR, Recital 37) whereas in Directive 2005/29, a commercial practice described as unfair if it "materially distorts or is likely to materially distort [...] economic behaviour" (Dir. 2005/29, Ch. 2, Art. 5, \$2[b]). ${ }^{31}$

The story does not end here; it is followed by a sequel. Sellers have no choice but to comply with the mandatory rules, which leads to amending sales practices. However, as the efficiency of the government behaviourally-informed policy puts a squeeze on their profits, sellers endeavour to reverse the effect of the government rule while remaining strictly compliant with it. What could be termed the reversal stage designs a third level of behaviourally-informed traps for the consumer. Although in the federal cooling-off rule above, no information is given as to whether tests were actually run on different agreement designs to assess impact on cancellations, the assumption made here is that sellers can rely on the specific framing of the agreement to bring about the reversal of the behaviourally-informed government mandate. The present study shows that the airline companies will act in compliance with EU rules, but that some of them will try to reverse the effects of the government mandate to make insurance purchase likely, thanks to the framing of the offer the consumer is asked to agree to. Language lies at the heart of behaviourally-informed framing reversal (or counter-nudging reversal).

\section{Practical legal compliance}

\subsection{Corpus selection}

19 Although EU legal provisions apply to all EU members, for the purpose of the present study on the use of framing in offers of insurance contracts in English, only offers written by native English-speaking lawyers, communications offices and web designers 
working for airline companies are relevant to our study. There are therefore only two countries in the EU which meet the native English-speaker requirement: the Republic of Ireland and the United Kingdom.

There are seven registered airline companies in Ireland: Aer Arann Islands, AerLingus, ASL Airlines Ireland, City Jet, Norwegian Air International, Ryanair, and Sobart Air. Among these companies, only three (AerLingus, City Jet, Norwegian Air International) offer website purchase services, and only two (AerLingus and Ryanair) offer additional insurance premium.

21 In the United Kingdom, there are twenty-five registered airline companies (type A operating licence holders). Of these companies only thirteen (BA City Flyer, BMI International, British Airways, Eastern Airways, EasyJet, Flybe, Jet2, Monarch Airlines, Norwegian Air UK, Thomas Cook Airlines, Thomson Airways, Virgin Atlantic Airways, Virgin Atlantic International) offer passenger travel services with website purchase access (as opposed to cargo or private charter services), and only five (British Airways, who owns BA City Flyer, EasyJet, Flybe, Jet2, Monarch Airlines) offer the possibility to purchase insurance.

\subsection{From non-compliance to compliance}

The assumption of compliance made earlier turns out to be correct for six of the seven companies selected. This is an unexpected feature which needs to be underlined here before moving on to the central study of the different compliance techniques of the other six companies.

Most offers of insurance services are similar to AerLingus's, presented in Figure 1:

Figure 1. Screenshot of AerLingus's insurance offer ${ }^{32}$

\section{Travel Insurance}
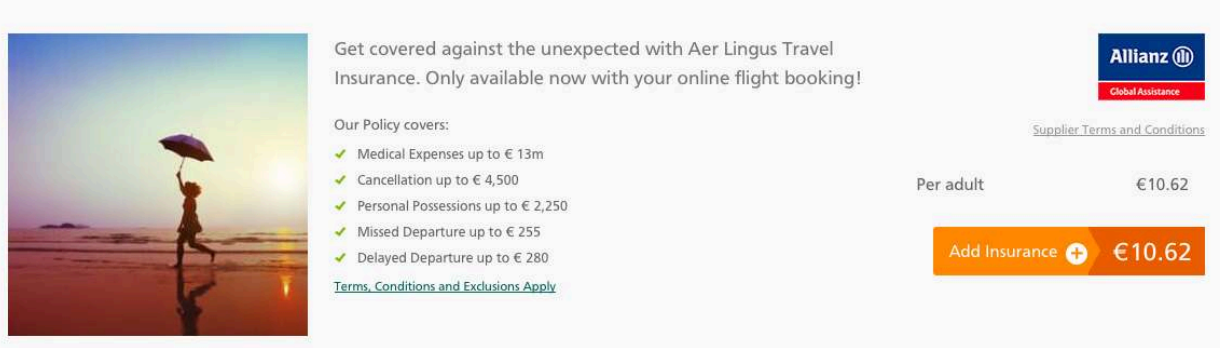

The terms of the offer of insurance services are listed. The customer is then required to click on the "Add insurance" button to mark agreement and add the cost of insurance to the final purchasing price. This requirement is compliant with EU law. Indeed EU law provides that businesses are not authorised to use pre-ticked default option:

Before the consumer is bound by the contract or offer, the trader shall seek the express consent of the consumer to any extra payment in addition to the remuneration agreed upon for the trader's main contractual obligation. If the trader has not obtained the consumer's express consent, but has inferred it by using default options which the consumer is required to reject in order to avoid the additional payment, the consumer shall be entitled to reimbursement. (CDR, Ch. 4, Art. 22) 

chosen different linguistic strategies to present their offers (see Table 1).

Table 1. Summary of the framing of the insurance travel offers

\begin{tabular}{|l|l|l|l|}
\hline Airline & $\begin{array}{l}\text { Is the travel } \\
\text { insurance offer } \\
\text { compliant? }\end{array}$ & $\begin{array}{l}\text { Framing of the acceptance of } \\
\text { the offer (affirmative } \\
\text { sentence) }\end{array}$ & $\begin{array}{l}\text { Framing of the refusal of } \\
\text { the offer (negative } \\
\text { sentence) }\end{array}$ \\
\hline AerLingus & Yes & Add insurance & $\begin{array}{l}\text { I don't need travel } \\
\text { insurance }\end{array}$ \\
\hline BA & Yes & I need travel insurance & \\
\hline Easyjet & Yes & Add insurance & \\
\hline
\end{tabular}




\begin{tabular}{|l|l|l|l|}
\hline Flybe & No & UK Single Trip $€ 14.27$ & Travel without insurance \\
\hline Jet2 & Yes & Yes, I need cover & No, already covered \\
\hline Monarch & Yes & Single Trip & No insurance \\
\hline Ryanair & Yes & Add to trip & \\
\hline
\end{tabular}

Framing is linked to the context in which the choice of purchasing insurance is offered to the consumer. The underlying assumption is that, as consumers do not always make rational choices, ${ }^{35}$ preference between options will depend on the frame (Tversky \& Kahneman op.cit.: 453). The framing of the acceptance of the insurance offer falls into two distinct categories: neutral provision of information (Idem) ${ }^{36}$ and offer framing.

\subsubsection{Neutral provision of information}

31

In the first category are AerLingus's, Easyjet's and Ryanair's offers. Their offers are presented as neutrally as possible in the imperative mode ("add") as a command or order to include the item into the list of additional features added to the final price. The semantic choice of the verb is consistent with widespread and acknowledged web practice to click on a basket icon, or on an "add" button, to add items to the virtual shopping cart. This construction is deemed neutral as it is consistent with web usage in the online goods and services industry.

\subsubsection{Offer framing}

32 Another type of construction is used which frames the acceptance or refusal of the offer using a full sentence (subject + verb + object) in the present tense. Two options are provided: either the affirmative or the negative. This construction can be deemed to be less neutral, as it directly invokes the opinion of the consumer.

With the use of the personal pronoun I, the consumer is personally summoned. The consumer is not only asked to decide in favour of one option or another, but $\mathrm{s} / \mathrm{he}$ is asked to make a personal commitment by standing in the shoes of a fictitious enarrator and impersonating him/her in voicing his/her agreement or disagreement. This construction which, as it were, puts words into the mouth of the consumer, might have similar effects on consumer commitment to the writing of the agreement in the federal cooling-off rule in the example discussed in Section 1 . The consumer is asked to virtually voice his/her commitment.

There is more to be said on the framing of the other options. Indeed, there is not only one sentence, but two: the affirmative sentence, followed (or preceded) by the negative one. The consumer is not asked to purchase, but to perform a more complex act: choose between two options. 
Table 2. Summary of the syntactic differences in the framing of the offer

\begin{tabular}{|c|c|c|c|c|}
\hline Airline & $\begin{array}{l}\text { Imperative } \\
\text { construction } \\
\text { (affirmative } \\
\text { sentence) }\end{array}$ & $\begin{array}{l}\text { Present } \\
\text { construction } \\
\text { (affirmative } \\
\text { sentence) }\end{array}$ & $\begin{array}{l}\text { Present } \\
\text { construction } \\
\text { (negative sentence) }\end{array}$ & Type of framing \\
\hline $\begin{array}{l}\text { AerLingus } \\
\text { Easyjet } \\
\text { Ryanair }\end{array}$ & $\begin{array}{l}\text { Add insurance } \\
\text { Add insurance } \\
\text { Add to trip }\end{array}$ & & & No framing \\
\hline BA & & $\begin{array}{l}\text { I need travel } \\
\text { insurance }\end{array}$ & $\begin{array}{l}\text { I don't need travel } \\
\text { insurance }\end{array}$ & $\begin{array}{l}\text { Positive/Negative } \\
\text { option framing }\end{array}$ \\
\hline Flybe & $\begin{array}{l}\text { UK Single Trip } \\
€ 14.27\end{array}$ & & $\begin{array}{l}\text { Travel without } \\
\text { insurance }\end{array}$ & $\begin{array}{l}\text { Positive/Negative } \\
\text { option framing }\end{array}$ \\
\hline Monarch & Single Trip & & No insurance & $\begin{array}{l}\text { Positive/Negative } \\
\text { option framing }\end{array}$ \\
\hline Jet2 & & Yes, I need cover & No, already covered & $\begin{array}{l}\text { Non-symmetrical } \\
\text { option framing }\end{array}$ \\
\hline
\end{tabular}

Table 2 identifies clearly the two distinct strategies airline companies adopt. As seen in section 2.3.1, the "Add" wording in AerLingus, Easyjet and Ryanair is prevalent in the online shopping experience and not relevant to the present study, as it does not exemplify any unusual type of framing. The second approach displays noteworthy instances of framing.

Among the option framing examples, two different sets of choices are presented to the would-be consumer. The first requires the consumer to determine his/her purchase according to a need s/he might or might not have for such a service. The option "I don't need an insurance travel" is the exact negative alternative of the affirmative "I need an insurance travel" offered as a first choice to the consumer. ${ }^{37}$ However, the second type is more unsettling as it does not offer mirror-options. The choice "No already covered" is in no way the negative option of the affirmative "Yes I need cover". This second type, called for lack of a better term "non-symmetrical option framing," is the focus of the last part of the study. It is of interest as it relies on implied meaning which contributes to nudge the consumer into buying an insurance policy. Jet2's strategy tries to reverse the primary aim of the EU behaviourally-informed initiative, which was to guarantee that the consumer would "take a transactional decision that he would not have taken otherwise" (Dir. 2005/29, Ch. 2, s. 1, Art. 6, \$1 and \$2; s. 1, Art. 7, $\S 1$ and §2; s. 2, Art. 8).

Indeed, Jet2's second option implies that the consumer has an insurance policy, an assumption that was not in the wording of the first option. In the previous wordings the consumer was asked to tick the box corresponding to his/her preferences (either s/ he needs or does not need insurance cover). However, the alternative above redetermines the options to choose from. The issue is no longer that of "need" (which is based on consumer-preference) but that of status: either I have, or I do not have 
insurance cover. The underlying idea is that if the consumer does not have an insurance, s/he has to buy one. The present alternative is very close to the options framed in Figure 3 below, where ticking the "I am not covered yet" box would automatically imply agreement to purchase an insurance policy:

Figure 3. Equivalent Wording of Jet2's Offer

I am already covered I am not covered yet

It is not impossible that this presentation might be found to undermine the effect of $\mathrm{EU}$ law. There is scope for arguing that this could be construed as a misleading omission under Article 7 \& 2 of Directive 2005/29 which mandates that:

It shall also be regarded as a misleading omission when, taking account of the matters described in paragraph 1, a trader hides or provides in an unclear, unintelligible, ambiguous or untimely manner such material information as referred to in that paragraph or fails to identify the commercial intent of the commercial practice if not already apparent from the context, and where, in either case, this causes or is likely to cause the average consumer to take a transactional decision that he would not have taken otherwise. (Dir. 2005/29, Ch. 2, s. 1, Art. 6, §1 and §2; s. 1, Art. 7, §1 and §2; s. 2, Art. 8)

The assumption made here is that the framing of the options by Jet2 is as close as possible to triggering the consumer response required in the moot wording in Figure 3 (Tversky \& Kahneman op.cit.: 457), ${ }^{38}$ without infringing its legal obligations under EU law. Ultimately, this is a question for the courts to decide. To determine whether the spirit of the law has been violated when the letter of the law has been strictly complied with, one will need experimental data on the effectiveness of such framing to convince a judge of the substance of the assumptions put forward in the present research.

However, in the absence of an empirical protocol of behavioural experiments on a sample group of consumers, the present study can only offer a theoretical assumption based on the existing literature on the topic.

\subsection{The narrative effect}

It has been established that Jet2 uses a human cognitive failing to nudge consumers into purchasing the insurance policy, a choice that they might not have made had the framing of the options been different. The grounds for the effectiveness of Jet2's framing can be found in the bias called "narrative fallacy" (Taleb 2010: 63). It refers to the fact that the human brain tends to respond favourably to perceived narrativity and causality as it is felt as an efficient way to tackle the uninterrupted flow of information, which is costly to obtain, to store, to manipulate and retrieve (idem: 63). Empirical studies prove that individuals respond more favourably to requests presented as narratives rather than to the same information provided in a non-narrative structure. ${ }^{39}$ Narrative structuration of information maximises a positive response to such a request.

How does psychology define the narrative structuration of information? Information will be structured narratively if it provides elements of storytelling. These elements will be introduced by identifying relations between the information provided (causality, chronology, etc.) (id.: 83-4). In defining narrative fallacy, Taleb refers to the work of E.M. Forster (1927). According to the latter, there are two elements to a narrative of events: a story and a plot. The story is a narrative of events arranged in 
time sequence (idem: 30$).^{40}$ The plot is a narrative of events, the emphasis falling on causality (id.: 86). To make his point, E.M. Forster gives the example of two sentences.

Sentence 1: The king died.

Sentence 2: The queen died.

In these two sentences, we are only given two unconnected thus unrelated events. This is not a narrative. If these two events are arranged in time sequence then this becomes a story "The king died and then the queen died"; or even a plot if causality is introduced by linking the second event to the occurrence of the first: "The king died, and then the queen died of grief."

Narrativity thus becomes apparent in the airline framing of options. BA's alternative "I need travel insurance/I don't need travel insurance" provides the consumer with an unconnected series of events/preferences. It is not so with Jet2's options "Yes, I need cover/No, already covered" which arrange information according either to implicit time sequence (first one is not covered, then one is covered) or to implicit causality (I need cover, because I am not covered/I do not need cover, because I am already covered).

In so ordering information, Jet2 creates an implicit narrative fallacy which taps into human bias for distinct patterns (Taleb op.cit: 50 ), and thus constitutes a powerful inducement to comply with the implicit request in the offer of insurance cover. The narrative fallacy could make it possible to deviate from the aim of EU directives and EU regulations applying to the industry, while at the very same time remaining strictly legally compliant.

The framing of the information in the Jet2 example takes advantage of the cognitive failings of consumers and their marked preference for a narrative structuration of information. In view of this theoretical approach, it is consistent to state that the consumer will be more likely to purchase the insurance. The provision of options is strictly legally compliant, but the framing of the information is misleading and it might be considered that Jet2 causes the consumer "to take a transactional decision that he would not have taken otherwise" (Dir. 2005/29, Ch. 2, s. 1, Art. 6, \$1 and \$2; s. 1, Art. 7, $\$ 1$ and \$2; s. 2, Art. 8), that is to contravene the mischief the law wished to eradicate. If the effect of the framing of options is as assumed here, then, as regards effects, there is room to argue that the legal compliance of the company could be considered as an unfair practice which aims to distort, and effectively distorts economic behaviour (Dir. 2005/29, Ch. 2, Art. 5, §2[b]), by exerting "psychological pressure" (CDR, Recital 37) on consumers to purchase. Although Jet2 complies with the letter of the law, it violates its spirit.

\section{Conclusion}

The conclusion drawn from the present study needs to be used with extreme caution. Indeed the theoretical analysis conducted here needs to be backed by empirical studies, which would assess the effective impact of framing on purchase. This is the reason why the paper is categorised as "exploratory research." Notwithstanding this caveat, there are some interesting elements which can be derived from this preliminary study. It has been established that some airline companies devise linguistic means to deviate from their legal obligations. 
51 The interest of the present paper is two-fold. The first is to identify that, contrary to the positions generally stated in the literature, counter-nudging of nudges is not - or at least should not be - a two-fold process. The first step usually consists in identifying areas where businesses use private nudges, i.e. behaviourally-informed strategies, to increase their sales. Governments then subscribe to counter-nudging to prevent companies from using consumer biases to enter into transactional agreements consumers would not have agreed to otherwise. However, there is evidence that businesses can then devise strategies to overturn the counter-nudging effect of mandatory legal provisions. In the present corpus relating to the offer of insurance packages by airline companies, the reversal of the counter-nudge (or counter-counternudge) is to be found in the framing of the offer. Although the issue of the effectiveness of such counter-counter-nudges is empirical, and thus needs to be established empirically, there is sufficient evidence in favour of considering the policy implications of this third step in devising behaviourally-informed government policies.

The second point derives from the first. The prohibition of pre-ticked boxes on ecommerce websites (CDR, Art. 22) is not enough to ensure that buyers can make private-nudge-free decisions on the market. Corporations will devise legally compliant strategies in response to government counter-nudges. In the case at hand, and in the absence of precise mandatory language guidelines concerning the wording of un-ticked boxes on websites, companies are free to phrase the acceptance of the offer in a way that will make consumer approval (and thus purchase) more likely. Governments need to set strict linguistic guidelines to prevent the reversal of their counter-nudging policies.

Even if more data collection is needed to establish the operation of narrative framing in behaviourally-informed EU legal provisions, there are strong arguments which point towards the need for harmonised linguistic framing to guarantee the effectiveness of consumer protection. Indeed the EU already imposes mandatory standards, as in the case of withdrawal forms. It should do so in relation to purchase options in online business.

\section{BIBLIOGRAPHY}

Legal provisions

Directive 2005/29

Directive 2011/83 (CDR)

Regulation 1008/2008

Web sources

Aer Lingus: <https://www.aerlingus.com>, retrieved on 26/2/2016.

Air Arann Islands: <http://www.aerarann.com>, retrieved on 15/6/2016. 
Air Tanker: <http://www.airtanker.co.uk >, retrieved on 15/6/2016.

ASL Airlines Ireland: <http://www.aslairlines.ie>, retrieved on 15/6/2016.

Atlantic Airlines: <http://www.westatlantic.eu >, retrieved on 15/6/2016.

BA City Flyer: <http://www.britishairways.com>, retrieved on 15/6/2016.

BAE Systems Corporate Air Travel: <http://www.baesystems.com>, retrieved on 15/6/2016.

BMI International: <http://www.bmiregional.com>, retrieved on 15/6/2016.

Bristow Helicopters: <http://www.bristowgroup.com>, retrieved on 15/6/2016.

British Airways: <http://www.britishairways.com>, retrieved on 15/6/2016.

Cargo Logic Air: <http://www.cargologicair.com>, retrieved on 15/6/2016.

City Jet: <http://www.cityjet.com>, retrieved on 15/6/2016.

Eastern Airways: <http://www.easternairways.com>, retrieved on 15/6/2016.

RVL Aviation: <http://ww.rvl-group.com>, retrieved on 15/6/2016.

Ryannair: <http://www.ryanair.com>, retrieved on 15/6/2016.

Sobart Air: <http://www.aerarann.com>, retrieved on 15/6/2016.

DHL Air UK: <http://www.dhl.com>, retrieved on 15/6/2016.

EasyJet: <http://www.easyjet.com>, retrieved on 15/6/2016.

Flybe: <http://www.flybe.com>, retrieved on 15/6/2016.

Jet2: <http://www.jet2.com>, retrieved on 15/6/2016.

Jota Aviation: <http://www.jotagroup.com>, retrieved on 15/6/2016.

Logan Air: <http://www.loganair.co.uk>, retrieved on 15/6/2016.

Monarch Airlines: <http://www.monarch.co.uk>, retrieved on 15/6/2016.

Norwegian Air International: <http://www.norwegian.com>, retrieved on 15/6/2016.

Norwegian Air UK: <http://www.norwegian.com>, retrieved on 15/6/2016.

TAG Aviation: <http://www.tagaviation.com/>, retrieved on 15/6/2016.

Thomson Airways: <http://www.thomson.co.uk >, retrieved on 15/6/2016.

Thomas Cook Airlines: < http://www.thomascookairlines.com>, retrieved on 15/6/2016.

Titan Airways: <http://www.titan-airways.com>, retrieved on 15/6/2016.

Virgin Atlantic Airways: <http://www.virgin-atlantic.com>, retrieved on 15/6/2016.

Virgin Atlantic International: <http://www.virgin-atlantic.com>, retrieved on 15/6/2016.

2Excel Aviation: <www.2excelaviation.com>, retrieved on 15/6/2016.

\section{Secondary sources}

ALEMANNO, A. 2015. "What can EU health law learn from behavioural sciences? The case of EU lifestyle regulation". In ALEMANNO, A. \& A-L. SIBONY (eds.), Nudging and the Law. What Can EU Law Learn from Behavioural Sciences? Oxford: Hart Publishing, 235-254.

ALEMANNO, A. \& A.-L. SIBONY (eds.). 2015. Nudging and the Law. What Can EU Law Learn from Behavioural Sciences? Oxford: Hart Publishing. 
ARKES, H. R. \& C. BLUMEr. 1985. "The psychology of sunk cost”, Organisational Behaviour and Human Decision Process 35, 124-140.

ARONSON, E. (ed.). 1995. The Social Animal, 7th ed. New York: W. H. Freeman.

AVGOULEA, E. 2009. "The global financial crisis and the disclosure paradigm in European financial regulation: The case for reform". European Company and Financial Law Review 6, 440-475.

AYRES, I. \& A. SCHWARTZ. 2014. “The no-reading problem in consumer contract law”. Stanford Law

Review 77, 545-610.

BAR-GILL, O. 2012. Seduction by Contract: Law, Economics and Psychology in Consumer Markets. Oxford: Oxford University Press.

BECHER, S.I. 2007. "Behavioral science and consumer standard form contracts”. Louisiana Law Review 68, 133-135.

BRUNON-ERNST, A. 2015. "The fallacy of Informed consent: Linguistic markers and contractual design in some e-users agreements". In ISANI, S. (ed.), Alicante Journal of English Studies 28, Lex/Lexis special issue, $37-58$.

CAROLAN, E. \& A. Spina. 2015. "Behavioural sciences and EU data protection law: challenges and opportunities". In ALEMANNO, A. \& A-L. SIBONY (eds.), Nudging and the Law. What Can EU Law Learn from Behavioural Sciences? Oxford: Hart Publishing, 161-178.

CIALDINI, R. B. 2007 [1984]. The Psychology of Persuasion. New York: Harper Collins.

CONLY, S. 2013. Against Autonomy: Justifying Coercive Paternalism. Cambridge University Press: New York.

FORSTER, E.M. 1927. Aspects of the Novel. San Diego: Harcourt.

KAHNEMAN, D. 2011. Thinking, Fast and Slow. New York: Farrar, Straus and Giroux.

NOLL, R.G. \& J.E. KRIER. 1990. "Some Implications of cognitive psychology for risk regulation". Journal of Legal Studies 19, 747-779.

LANGER, E. 1989. Mindfulness. Cambrige, MA: Perseus Books.

PLous, S. 1993. The Psychology of Judgment and Decision Making. New York: McGrawHill.

SIBONY, A. \& G. HELLERINGER. 2015. "EU consumer protection and behavioural sciences". In ALEMANNO, A. \& A-L. SIBONY (eds.), Nudging and the Law. What Can EU Law Learn from Behavioural Sciences? Oxford: Hart Publishing, 209-234.

SOUSA LOURENCO J., E. CIRIOLO, S. RAFAEL RODRIGUES VIEIRA DE ALMEIDA \& X. TROUSSARD. 2016. Behavioural Insights Applied to Policy: Overview across 32 European Countries, European Report 2016, retrieved from <http://publications.jrc.ec.europa.eu/repository/handle/JRC100146> on 5 March 2016. SUnSTEIN, C. 2014. Why nudge? The Politics of Libertarian Paternalism. New Haven: Yale University Press.

SUNSTEIN, C. \& R. THALER, R. 2008. Nudge: Improving Decisions About Health, Wealth and Happiness. New Haven: Yale University Press.

TALEB, N. N. 2010 [2007]. The Black Swann: The Impact of the Highly Improbable. New York: Random House.

TVERSKY, A. \& D. KAHNEMAN. 1981. "The framing of decisions and the psychology of choice". Science 211/4481, 453-458. 
VAN BAVEL, R., B. HERRMANN, G. ESPOSITO \& A. PROESTAKIS. 2013. Applying behavioural sciences to EU policy-making. JRC Scientific and Policy Reports. Retrieved from <http://ftp.jrc.es/EURdoc/ JRC83284.pdf> on 15 June 2016.

VAN CLEYNENBREUGeL, P. 2015. "Conduct of business rules in EU financial services". In ALEMANNo, A. \& A-L. SIBONY (eds.), Nudging and the Law. What Can EU Law Learn from Behavioural Sciences? Oxford: Hart Publishing, 255-276.

ZUIDERVEEN BORGESIUS, F. 2015. "Behavioural sciences and the regulation of privacy on the Internet". In ALEMANNO, A. \& A-L. SIBONY (eds.), Nudging and the Law. What Can EU Law Learn from Behavioural Sciences? Oxford: Hart Publishing, 179-208.

\section{NOTES}

1. See for example Article 22 in Directive 2011/83 (hereafter CDR) which defines the way in which information is given to the consumer. It states: "If the trader has not obtained the consumer's express consent but has inferred it by using default options which the consumer is required to reject in order to avoid the additional payment, the consumer shall be entitled to reimbursement of this payment."

2. See for example Annex 1 in CDR which outlines the model withdrawal form.

3. The directives considered in the corpus are: Directive 2005/29 on unfair business-to-consumer commercial practices in the internal market, Directive 2011/83 on consumer rights (CDR), which impose strict linguistic obligations on sellers, and Regulation 1008/2008 on price information disclosure in the travel industry.

4. The term "framing" is used by psychologists and behavioural economists to describe the process by which the context (including its formulation) of acts or options among which one must choose (decision problem) serves to influence the possible outcome of the decision.

5. Conly defines paternalism as: "a practice wherein people are forced to perform actions that bring about good consequences for themselves." It is the beneficent aim of the interfering initiative devised by the paternalist with respect to a dependent that determines the paternalistic nature of the intervention on choice.

6. Sunstein explains that a "choice architect has the responsibility for organising the context in which people make decisions."

7. Contract design is another more limited type of technique which determines the use of certain contractual terms to circumscribe consumer options.

8. See note 2 above.

9. See note 3 above: for instance, the wording of Article 22 in CDR ("If the trader has not obtained the consumer's express consent but has inferred it by using default options which the consumer is required to reject in order to avoid the additional payment, the consumer shall be entitled to reimbursement of this payment").

10. Sunstein was the head of the Office of Information and Regulatory Affairs. Under the influence of Thaler, a Behavioural Insights Team was created in the UK (known as the Nudge Unit) and recently the European Commission has set up the Foresight and Behavioural Insights Unit.

11. See Directive 2005/29 on unfair business-to-consumer commercial practices in the internal market, and CDR, which impose strict linguistic obligations on sellers.

12. René van Bavel, Benedikt Herrmann, Gabriele Esposito and Antonios Proestakis recommend the application of BIs to EU energy law by giving the example of the UK tax letter devised by the UK Nudge Unit (Behavioural Insights Team, "Behaviour Change and Energy Use" [2011]). 
13. In Applying Behavioural Sciences to EU Policy-making (2013), the authors recommend the application of BIs to EU taxation law by giving the example of the UK test carried out by the UK Nudge Unit to induce energy savings (Behavioural Insights Team, "Applying Behavioural Insights to Reduce Fraud, Error and Debt" [2012]).

14. See Regulation 1008/2008, which regulates information disclosure (among others) in the travel industry.

15. On this point, see the literature on the "no-read" phenomenon. It refers to the fact that consumers do not read contracts, although they have to sign to confirm they have read and understood all the terms.

16. Data processing limitations refer to the fact that consumers are given too much information they are unable to process in the time available.

17. The sunk-cost effect is manifested in a greater tendency to continue an endeavour once an investment in time, money or effort has been made. The concept of sunk-cost effect, as it is used in behavioural economics, is similar to the "commitment rule" in psychology.

18. The principle of cognitive dissonance means that individuals are reluctant to hold to conflicting ideas simultaneously. The concept of sunk-cost effect, as it is used in behavioural economics, is similar to the "consistency rule" in psychology.

19. The confirmation bias can be related both to the principle of cognitive dissonance and to the sunk-cost effect. This bias shows that, when reading information, individuals seek information which will confirm their already held opinions rather than challenge them.

20. The herding effect means that buyers will tend to trust an agreement they know others have entered into.

21. Consumer over confidence means that buyers tend to think that small type or unfavourable provisions making amends for unexpected events are unlikely to happen to them.

22. The low-ball technique is a procedure by which a consumer underestimates or understates a price.

23. Low-probability risk refers to the fact that individuals tend to underestimate low-probability risks that may have very dire consequences for them, such as dying in a plane crash.

24. Availability cascade refers to the fact that individuals overestimate risk when a risk-prone activity has already been called to mind.

25. Self-serving biases refer to the fact that individuals tend to believe they are immune to risk.

26. See notes 17 and 18 above.

27. The EU Foresights and Behavioural Insights Unit has identified three different applications of behavioural insights: (1) default effect; (2) framing; (3) myopic decision-making. See <https:// ec.europa.eu/jrc/en/research/crosscutting-activities/behavioural-insights/commission> retrieved 3 March 2016.

28. See the importance of loss aversion in the Prospect Theory devised by Kahneman and Tversky (2011).

29. Neither does the EU Foresights and Behavioural Insights Unit forget to counter the human tendency to overweigh small probabilities, which is extensively studied by contract law behavioural economists.

30. 16 CFR Part 429.

31. Determining an unfair practice is a two-pronged test. The first condition is that the practice be "contrary to the requirements of professional diligence" (Dir. 2005/29, Ch. 2, Art. 5, §2[a]).

32. See <https://www.aerlingus.com>, retrieved on 26/2/2016

33. CDR states that passenger transport is excluded from the scope of the directive. However, all the provisions relative to excessive fees or hidden costs also apply to passenger contracts. See CDR, Recital 27. 
34. See < http://www.flybe.com>, accessed on 26/2/2016. Monarch Airlines insurance offer has a scroll-down menu, with the option "No insurance" as the default option. See <http:// www.monarch.co.uk>, retrieved on 15/6/2016.

35. The very existence of an EU Behavioural Insights Unit is evidence that EU policy-makers do not believe that consumers' choices are founded on the assumption of rationality. However, Sibony and Helleringer (op.cit.: 214-9) show that the Court of Justice of the European Union refers to an idealised average EU consumer in its judgments at odds with empirical evidence highlighted by behavioural science.

36. It could be argued that there is a frame to all options, as any frame is controlled partly by the formulation of the problem and partly by the norms, habits, and personal characteristics of the decision-maker. Here the neutral option complies with the accepted norm in the field of the ecommerce industry.

37. More needs to be done to assess the impact of the framing of the decision along the lines of positive/negative options. Indeed, the literature stresses the fact that choices involving gains are often risk averse and choices involving losses are often risk taking. How does a negative framing of options bear upon this psychological bias?

38. Another possible direction of study would involve looking into how the nature of insurance provision influences the choice of consumers. By its nature, insurance taps into human fear of harm and the need to ensure security. Research shows that insurance appears more attractive when it is presented as elimination of risk rather than when it is described as a reduction of risk. Are Jet2's options framed in such a way to highlight protective action which would follow purchase of insurance coverage?

39. See the study on the phrasing of a question to jump the queue at a photocopying machine (Langer 1989: 14).

40. Forster distinguishes a story from a plot.

\section{ABSTRACTS}

Behavioural science has established that consumers' decisions are affected by cognitive biases preventing them from making rational choices that would increase their overall welfare. Sellers use these systematic misconceptions to increase sales. As a consequence, governments need to step in to protect consumers by imposing mandatory guidelines informed by behavioural sciences in order to prevent sellers from taking an unfair advantage of these biases. After studying the theoretical and legal framework of behaviourally-informed policies, the paper explores how the provision of insurance services at the time of purchase of a travel ticket is framed and shows how some companies use framing to comply with the letter of EU law while at the same time violating its spirit. The different linguistic strategies used show that, paradoxically, businesses' strict legal compliance can display misleading options, which seek to overturn the effects of the EU behaviourally-informed initiatives.

La théorie économique classique est fondée sur le présupposé que, lors d'un achat raisonné, les consommateurs choisissent l'offre la plus intéressante pour eux. En pratique, leurs décisions restent influencées par des biais cognitifs. Les entreprises exploitent ces erreurs systémiques. Les gouvernements interviennent alors souvent pour corriger ces asymétries qui fonctionnent au détriment des consommateurs. Après avoir étudié le cadre théorique et juridique des politiques 
fondées sur les apports des sciences comportementales, l'article examine, dans le cadre de l'offre d'assurances au moment de l'achat de vols sur internet, comment certaines entreprises jouent avec la formulation de leurs offres pour se plier à la lettre de la loi tout en en violant l'esprit. Paradoxalement, bien que se conformant au droit européen, les entreprises peuvent contourner ces initiatives de protection des consommateurs en utilisant des stratégies linguistiques de cadrage de l'information (framing), que l'article explore.

\section{INDEX}

Mots-clés: cadrage, contrat de consommation, contre-nudge, droit européen, nudge Keywords: consumer contract, counter-nudge, EU law, nudge, framing

\section{AUTHOR}

\section{ANNE BRUNON-ERNST}

Anne Brunon-Ernst is Professor in Legal English at Panthéon-Assas University (Paris, France), and researcher at the Cersa (Panthéon-Assas) and at the Centre Bentham (ScPo, Paris). Her research interests focus on Jeremy Bentham's thought and its contemporary reappropriations. She is the author of numerous articles and books, among which Utilitarian Biopolitics (Pickering and Chatto, 2012) and Beyond Foucault (Ashgate, 2012). anne.brunon-ernst@u-paris2.fr 